\title{
Cognate and Non-Cognate Lexical Access in Turkish of Bilingual and Monolingual 5 year-old Preschool Children
}

\author{
Mehmet Ali Akınci ${ }^{1}$ \\ ORCID ID: ${ }^{10000-0002-7077-4322 ~}$ \\ ${ }^{1}$ Rouen Normandie University, Laboratoire Dynamique du Langage in Situ \\ (DYLIS), Rouen, France \\ ${ }^{1}$ Mehmet-Ali.Akinci@univ-rouen.fr
}

(Received 12 May 2021; Accepted 8 October 2021)

\begin{abstract}
This study aims to characterize the influence of lexical proximities between cognate and non-cognate words on conceptual access in Turkish and French of bilingual children from Turkish immigrant families in France. In order to do this, 16 French-Turkish bilingual, 16 French monolingual and 20 Turkish monolingual 5-year-old preschool children participated to a picturenaming test composed of (i) cognate and (ii) non-cognate nouns in both languages. Our results reveal a high level of performance in cognate word recognition for French-Turkish bilinguals. This proves that these bilingual children implicitly knew these common words. On the one hand, this result questions the idea according to which a bilingual would not use words resulting from their L1 when they produce the word in their L2; and, on the other hand, it supports arguments in favor of the theory according to which both languages are activated for bilinguals even when using only one language.
\end{abstract}

Keywords: Turkish, lexical access, cognates/non-cognates, bilingual children, preschool, Turkish migration, France

\section{Yaş Okul Öncesi Dönemdeki Tek Dilli ve İki Dilli Çocukların Türkçede Eşasıllı ve Eşasıllı Olmayan Sözcüklere Sözlüksel Erişimi}

ÖZ: Bu çalışma Fransa'da yaşayan Türkçe-Fransızca iki dilli çocukların eşasııllı olan ve olmayan kelimeler arasındaki sözlüksel yakınlığın kavramsal erişim üzerindeki etkisini incelemeyi amaçlamaktadır. Çalışmada 5 yaş grubundan 16 Fransızca-Türkçe iki dilli, 15 Fransızca tek dilli ve 20 Türkçe tek dilli çocuk her iki dilde i) eşasılllı ve ii) eşasıllı olmayan adlardan oluşan resim adlandırma testine katılmıştır. Sonuçlar Fransızca-Türkçe iki dilli çocukların eşasıllı kelime 
tanıma testinde yüksek bir başarı göstediklerini işaret etmektedir. Bu sonuç iki dilli çocukların örtük bir şekilde bu ortak kelimeleri bildiklerini kanıtlamaktadır. Bu sonuç bir yandan bir iki dillinin D2'de bir sözcük üretirken D1'den gelen bir sözcüğü kullanmayacağı görüşünü tartışmaya açarken diğer yandan sadece tek dil kullanıldığında bile her iki dilin etkinleştirildiği teorisinin lehinde olan tartışmaları desteklemektedir.

Anahtar sözcükler: Türkçe, sözlüksel erişim, eşasıllı/eşasılllı olmayan, iki dilli çocuklar, okul öncesi, Türk.göçü, Fransa

\section{Introduction}

Within his studies on acquiring the L2 vocabulary, Bogaards (1994) introduces the notion of lexical transparency between a word and its translation equivalent (for example, the French word zèbre and its Turkish translation equivalent zebra). It is because these transparent translation equivalents seem to receive special treatment that they are generally grouped together under the term "cognates". This term applies to all words which have an orthographic and phonological form close to their translation equivalent in another language (De Groot, 1993; Kroll \& De Groot, 1997; Woutersen, de Bot \& Weltens, 1995). In contrast, the term "non-cognate" applies to translation equivalents whose orthographic and phonological forms are relatively distant (example: banane in French and muz in Turkish). Thus, part of recent research on bilingual lexicon and its organization is devoted to the study of the representation of cognate words in memory. Bilinguals name pictures more quickly and with fewer errors with cognate names than non-cognates (e.g., Costa, Caramazza, \& Sebastian-Galles, 2000; Ivanova \& Costa, 2008; Kohnert, 2004). Although there is still a debate about what drives cognate facilitation effects, the different accounts are not mutually exclusive. The differences in performance generally observed between cognates and non-cognates would be an argument in favor of different representations in memory for each of the classes. The study of the treatment of these particular words would then make it possible to better apprehend the complexity of the bilingual lexicon organization.

The main purpose of this paper is to study the influence of lexical proximities between cognate and non-cognate words on conceptual access in Turkish and French of bilingual children from Turkish immigrant families in France. Studies focusing on young children of Turkish immigrant parents in France have revealed that, aged 5-10, these children show poor performance in the comprehension and production of phonology, and face serious difficulties at the lexical and morpho-syntactic levels. At the lexical level, studies such as Chalumeau \& Efthymiou (2010) and Le Coz \& Lhoste-Lassus (2011) have demonstrated that the vocabulary span of five-year-old bilingual preschool 
students of Turkish descent are more limited compared to their monolingual peers. Based on these findings, we aim, in this study, to compare the access of French-born bilingual 5-year-olds and their French and Turkish-born monolingual counterparts to cognate and non-cognate words in their French and Turkish use.

The sample group of this study consists of 16 French-Turkish bilingual, 20 Turkish monolingual and 16 French monolingual 5-year-old preschool students. We used a picture-naming test including (i) cognate and (ii) non-cognate words in both languages. Then a list of 46 items involving 25 cognates and 21 noncognates that are likely to be produced by children in this age group was established from several picture-naming tests that are conventionally used in speech therapy with same age children.

This paper is composed of three sections. In the first section, we present the theoretical framework, and focus particularly on the reasons behind the French and Turkish interface. In the second section, we put forward our methodology for data collection and analysis and describe our participants. In the last section, we analyze the results of the picture-naming test for all groups concerned.

\section{Bilingualism in Children of Immigrant Families with Turkish Background in France}

Research on language development in children from Turkish migrant families has been carried out from sociolinguistic and psycholinguistic perspectives (Manigand 1999; Akinci 2001; Akinci 2006, Akinci \& Decool-Mercier 2010; Hamurcu-Süverdem 2015, Ertek 2017; Oker \& Akinci 2012).

Previous studies have shown that there is fast improvement in the French competence of children from immigrant Turkish families after they start preschool education at ages 2-3; by the end of preschool, when they are 5-6 years old; French becomes the language in which they are most competent (Akinci, 2001). Even if their Turkish continues to develop in this period, their competence in this language decreases with age. It has also been revealed in the above-mentioned study that when they are at ages 5-6, these children are in a state of "skill-deficiency" compared with their monolingual peers in France and Turkey. Their use of word order is one indication of this deficiency. Yet, although this deficiency can be overcome in French when children are 7 years old, this can be realized in Turkish only around ages 14-15 (Akinci, 2006). This finding alone indicates the importance of language and culture education in the first language development and use, especially in the case of second-generation immigrant youth.

Based on preschool teachers' complaints about bilingual Turkish children's observed difficulties at the lexical and morpho-syntactic levels, in a comparative study, Le Coz and Lhoste-Lassus (2011) focused on 20 bilingual 
and 20 monolingual French children around age 5. Analyses of data collected both in French and in Turkish revealed that compared with monolingual children, bilingual children show lower performance in naming tests except for color names. An interesting finding from the study is that upon seeing an unfamiliar word, bilingual children keep silent while monolinguals produce other words as answers, such as supplying "penguin" or "chicken" when seeing the picture of a "duck."

In the same study, in morpho-syntactic tests, differences in terms of both comprehension and production have been observed between monolinguals and bilinguals. Bilinguals made some critical mistakes in gender of words (masculine, feminine), contracted articles, and plural verb conjugations. Out of 20 bilingual children, two were identified as having serious difficulties, and remarkable delays in their French were spotted while they had better levels in Turkish. This finding proves that some children in this age group remain more competent in Turkish. Meanwhile, bilingual children were observed using French words at certain times in narratives that were supposed to be in Turkish. Using a word from a language that they know well in order to replace a word that they do not seems to be a solution they found. It should be noted, again, that this strategy was employed only in stories told in Turkish.

The results show that home language practices have an impact on interactional and language competences of children.

\subsection{Lexical Development in Bilingual Children}

As laid out above, many studies confirm that children from Turkish immigrant families have serious lexical deficits in preschool years. Research explains the lexical deficit in bilingual Turkish-speaking children by the typological distance between Turkish and French, and the phonological difficulties that they experience due to it.

The bilingual lexicon seems to be a result of the Complementarity Principle as defined by Grosjean (2010). This principle suggests that bilingual children use their languages for different purposes, with different people, and in different areas. Grosjean argues that the Complementarity Principle has various consequences, such as the lack of one-to-one correspondence between first language and second language lexicons. In this case, because the fields in which the language is used might be different across languages, bilinguals do not have to develop the same skills in both languages. 


\subsection{Assessment of the Bilingual Lexicon}

Especially given the fact that bilinguals' skills and knowledge are complementary in two languages, it is unsound to assess bilingual children with tests designed for monolinguals and compare them with monolinguals.

In order to avoid misleading results, and to assess the lexical proficiency of bilinguals more accurately, various scoring rubrics have been developed in recent years (Bornstein et al. 2004). Pearson et al. (1993) proposed a differentiation among 'monolingual,' 'total' and 'conceptual' scores. Monolingual score is the number of all lexical items in any of the child's language (first or second); total score is the total of all lexical items in all the languages in the child's repertoire; and conceptual score is the number of concepts in the child's repertoire.

Many different studies (Junker \& Stockman, 2002; Zablit \& Trudeau, 2008) demonstrate that simultaneous bilinguals score lower than monolinguals in terms of lexicon in each language (monolingual scores). Yet, when the conceptual lexicon is analyzed, they are found to obtain scores equal to monolinguals'; and in terms of holistic scores, they sometimes obtain higher scores than monolinguals (de Houwer, 2010; de Houwer et al, 2013). The lower scores bilingual children obtain in terms of monolingual lexicon can be explained by the Complementarity Principle (Grosjean, 2010). Genesee et al. (2011) underline that lexical acquisition involves coding each new item individually, which requires a lot of time, children need to encounter each item multiple times, and is particularly costly in terms of memory resources.

\subsubsection{A Model for Lexical Acquisition in the Second Language}

The best-known theoretical model for second language lexical acquisition is the Revised Hierarchical Model proposed by Kroll \& Stewart (1994). This model emphasizes the matching of new words in the second language with the concepts already present in memory. Yet, like the late bilinguals (6 - 11 years old), early sequential bilinguals ( $3-6$ years old) have to develop many different concepts as they start to learn a second language, and the model is important in terms of understanding their development. A person learning a new language makes connections between the lexical repertoires of the two languages. As the languages are used and the experience of second language increases, these connections get stronger. Yet, according to this model, there is an asymmetry between these connections; the lexical connections between the second language (L2) to the first (L1) are much stronger than the connections from L1 to L2. In this model, a person learning a new language co-activates a word that he/she produces and understands in L2 with the equivalent of a word that is translated from L1. Meanwhile, an advanced learner/speaker does not use a translation equivalent of L1 when using a word in L2. 


\subsubsection{Vocabulary Use in Bilinguals}

Conventionally, the active lexicon in children has been assessed through picture-naming tests. Tests of this kind involve the process of lexical access and particularly matching the word in the memory with the concept that the person wants to express.

In the context of bilingualism, a person makes use of two different words in his/her two different languages in order to express a certain concept. This brings into question a number of issues. Studies conducted in the last 30 years have sought to identify the process of producing a lexical item expressing a concept that a bilingual wishes to express at the right time in the right language. In other words, research has sought to resolve the mechanism of lexical access in bilinguals.

Research today has now confirmed that when they produce a word in L2, advanced bilinguals do not use L1 word repertoire at all. At the same time, many studies (Costa \& Santesteban, 2004; Costa, Santesteban \& Ivanova, 2006) have demonstrated that while using vocabulary in L2, both languages are in a functional parallelism, and the language that is out of use is still active in the brain. Bilinguals' capacity to parse the languages in their brain while using their languages proves that they have very effective cognitive control mechanisms.

\subsubsection{Lexical Selection}

According to Inhibitory Control Model (Green, 1998), every word is tagged as belonging to a particular language. Words that belong to the non-target language will therefore be inhibited while accessing the target word. From this point of view, lexical competition takes place independently of language, that is, lexical units in different languages can be simultaneously activated, and the lexical unit with the highest level of activation will be produced. The use of a word from a non-target language can be seen as resulting from a lack of inhibition.

On the other hand, scholars like Costa et al. (1999), Costa \& Caramazza (1999) argue the opposite, and claim that lexical choice mechanism is languagedependent. They propose that the selection mechanism in the activation of lexical representations operates only in the target language. They emphasize that the lexical representation of language items in the non-target language are activated but are not taken into consideration in lexical selection.

\subsubsection{Cognates in the Bilingual Lexicon}

One of the approaches researchers employ in understanding whether the nontarget language is active and usable in lexical selection is to analyze words with 
certain properties that are shared between the two languages of bilinguals. Studies have been conducted on homographs, which are spelled alike in both languages, and cognates, which are pronounced alike (Kroll et al., 2008, Yan, 2014). Cognates are words that share a similar spelling and phonology in different languages and mostly retain their meanings. However, studies do not always confirm the level of similarity between these words in the case of translation equivalents (Font \& Lavaur, 1998).

Many studies contend that compared to non-cognates, cognates ease the process of lexical selection in bilinguals (Broersma et al. 2016). This easing effect is usually seen as evidence for parallel activation in the two languages. If the target language alone is activated, bilinguals' access to cognate and noncognate words should not be different.

The ease of processing in cognates is seen both in word comprehension / recognition (Font \& Lavaur, 1998; Dijkstra et al., 1999; Dijkstra et al., 2010) and production (Kroll \& Stewart, 1994; Costa, Caramazza \& Sebastian-Galles, 2000; Costa, Santesteban \& Cano, 2005; Brenders et al., 2011; Poarch \& Van Hell, 2012). In the case of oral production, studies in picture-naming tests show that pictures of cognate words are named faster (Costa, Caramazza \& Sebastian-Galles, 2000). At the same time, these words are seen more prone to tip-of-the-tongue effects (Gollan \& Acenas, 2004), and easier to learn (Comesaña, Soares \& Lima, 2010). Also, it has been shown that these words decrease the number of word errors in both the dominant and non-dominant language.

Experiments on cognates have been conducted with individuals learning a language at later ages. The purpose of our study is to analyze the case of access to these two types of words in French-Turkish children of immigrant families who can be described as early sequential bilinguals. Our overarching research question is whether these children show better skills in their use of cognates compared to non-cognate words.

\section{Methodology}

\subsection{Participants}

Turkish-French speaking 5-year-old final-year preschool students were selected from the Turkish immigrant community in various Kindergartens of the city of Tours in central France, particularly in the district of Romorantin-Lanthenay.

In order to select monolingual French children, we paid attention to the same criteria as above except for 3 and 4 . In order to check whether participants suit our criteria, we designed a questionnaire for the families. Questionnaires were prepared both in French and Turkish to ensure the bilingual families did not have any problems understanding the questions. 
Following these criteria, 16 bilingual Turkish-French, 16 monolingual French in France, and 20 monolingual Turkish speaking 5-year-olds enrolled in preschool in Turkey formed our participant group.

Table 1 below gives the details of the bilingual and monolingual informants, as gathered through questionnaires filled out by families.

Table 1. Information on range of ages, sex, birth order, and parental occupation of bilingual and monolingual participants

\begin{tabular}{|c|c|c|c|c|c|}
\hline $\begin{array}{l}\text { Participant } \\
\text { Groups }\end{array}$ & $\begin{array}{c}\text { Range of } \\
\text { Ages }\end{array}$ & Gender & Birth Order & $\begin{array}{c}\text { Father's } \\
\text { Occupation }\end{array}$ & $\begin{array}{l}\text { Mother's } \\
\text { Occupation }\end{array}$ \\
\hline $\begin{array}{l}\text { Bilingual } \\
(\mathrm{n}=16)\end{array}$ & $5 ; 4-6 ; 3$ & $\begin{array}{l}8 \text { Girls } \\
8 \text { Boys }\end{array}$ & $\begin{array}{c}\text { 1st }(n=6) \\
\text { 2nd or 3rd } \\
\quad(n=4) \\
4 \text { th }(n=2)\end{array}$ & $\begin{array}{c}\text { Worker } \\
(\mathrm{n}=11) \\
\text { Trader }(\mathrm{n}=3) \\
\text { Unemployed } \\
(\mathrm{n}=2)\end{array}$ & $\begin{array}{c}\text { Housewife } \\
(n=14) \\
\text { Worker }(n=2)\end{array}$ \\
\hline $\begin{array}{l}\text { Monolingual } \\
\text { French } \\
(\mathrm{n}=16)\end{array}$ & $5 ; 3-6 ; 6$ & $\begin{array}{l}8 \text { Girls } \\
8 \text { Boys }\end{array}$ & $\begin{array}{l}\text { 1st }(n=8) \\
\text { 2nd }(n=5) \\
\text { 3rd }(n=2) \\
\text { 4th }(n=1)\end{array}$ & $\begin{array}{l}\text { Worker }(n=5) \\
\text { Office } \\
\text { Worker }(n=5) \\
\text { Professional } \\
\quad(n=5) \\
\text { Unemployed } \\
\quad(n=1)\end{array}$ & $\begin{array}{c}\text { Housewife } \\
(n=14) \\
\text { Worker }(n=2)\end{array}$ \\
\hline $\begin{array}{l}\text { Monolingual } \\
\text { Turkish } \\
(n=20)\end{array}$ & $5 ; 4-6 ; 5$ & $\begin{array}{l}10 \text { Girls } \\
10 \text { Boys }\end{array}$ & $\begin{array}{c}1 \mathrm{st}(\mathrm{n}=6) \\
2 \mathrm{nd}(\mathrm{n}=5) \\
3 \mathrm{rd}(\mathrm{n}=5) \\
4^{\mathrm{th}}(\mathrm{n}=4)\end{array}$ & $\begin{array}{l}\text { Worker } \\
(n=20)\end{array}$ & $\begin{array}{l}\text { Housewife } \\
(n=15) \\
\text { Worker }(n=5)\end{array}$ \\
\hline
\end{tabular}

Table 2. Language use in bilingual children

\begin{tabular}{lcccccc}
\hline $\begin{array}{l}\text { Language } \\
\text { Use }\end{array}$ & $\begin{array}{c}\text { With } \\
\text { Mother }\end{array}$ & $\begin{array}{c}\text { With } \\
\text { Father }\end{array}$ & $\begin{array}{c}\text { With } \\
\text { Siblings }\end{array}$ & $\begin{array}{c}\text { With } \\
\text { Peers }\end{array}$ & $\begin{array}{c}\text { Lang. that } \\
\text { requires } \\
\text { effort }\end{array}$ & $\begin{array}{c}\text { Better } \\
\text { understood } \\
\text { lang. }\end{array}$ \\
\hline Turkish (T) & 9 & 7 & 4 & 1 & 1 & 10 \\
French (F) & 1 & 2 & 1 & 4 & 11 & 1 \\
Both T \& F & 4 & 7 & 11 & 11 & 3 & 5 \\
No & 2 & & & & 1 & \\
Comment & & & & & & \\
\hline
\end{tabular}

Table 2 above presents language preferences of bilingual children in order to understand their use of the two languages and to evaluate our findings better. 
The information in these tables suggest that Turkish is used heavily in communication with the mothers, while children talk more bilingually with the fathers. With siblings and peers, bilingual children are observed to use mainly both languages. From the perspective of parents, the language that requires more effort is French, while the language that is understood better by the children is Turkish.

\subsection{Selection of Cognate and Non-cognate Words}

A total of 4974 words have entered Turkish from or through French ${ }^{1}$. In order to select the cognates, we have been inspired by a study that to list all transparent words between French and Turkish (Kara, 2011). Out of this list, we have formed a group of words that are likely to be produced by 5-year-old final year preschool students. We have analyzed each word in order to make sure they carry the same meaning in both French and Turkish. For instance, we excluded words that have entered Turkish from French and been through a meaning shift, such as the word 'eşofman' from the word "échauffement" in French ("warm-up") which in Turkish has taken the meaning of "jogging". In addition, we have also tried to select items that are culturally neutral. All of the words we have selected belong to the noun category.

In order to ensure that the selected words are familiar to 5-year-olds and do not appear vague, we ran a pilot test with 17 monolingual French-speaking children living in cities and suburbs. From the results of this pilot test, we took for granted as acquired for this age-group, an item for which more than $75 \%$ of the children had given the expected answer, either spontaneously or on phonetic clues (Morrison et al., 1997).

In selecting non-cognate words, we based our list on various naming tests that are conventionally used to measure vocabulary by speech therapists with 5-year-old children in France.

Thus, taking the results of the pilot test into consideration, our final list consists of 46 words ( 25 cognate and 21 non-cognate ${ }^{2}$ ) that can be produced by 5 -year-olds. We selected pictures that are used in the tests from Google Images as below.

\footnotetext{
${ }^{1}$ According to Sağlam (2007: 175) "While a total of 6391 words, 1083 of which are terms, have entered Turkish from or through Arabic; a total of 4939 words, 2305 of which are terms, come from or through French".

${ }^{2}$ Originally, we planned to test at least 20 items and finally took more in case some items might be a problem for the children, which is why the number of items is not equal between the cognate words and non-cognate ones.
} 
Figure 1. Some examples of images used for picture-naming test

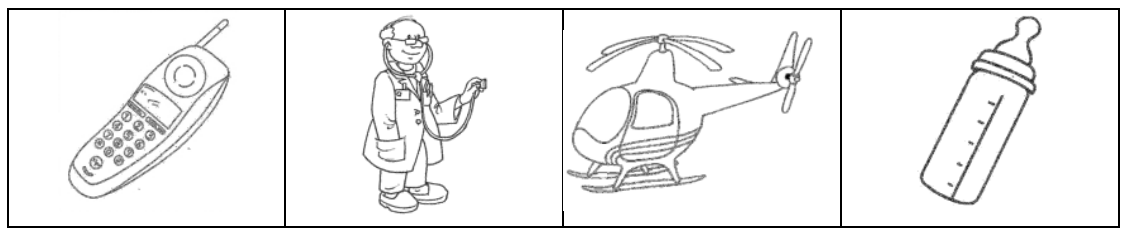

Assuming that colors might carry different cultural meanings across the two languages (e.g., "ambulance" or "police car"), we chose only black and white images.

Table 3 below lists the 25 cognates and 21 non-cognates we have compiled for both bilingual and monolingual participants.

Table 3. List of the 25 cognates and 21 non-cognates in French and in IPA spelling, with their English translations

\begin{tabular}{|c|c|c|c|c|c|}
\hline \multicolumn{3}{|c|}{ Cognate words } & \multicolumn{3}{|c|}{ Non cognate words } \\
\hline French & $\begin{array}{l}\text { Turkish use } \\
\text { (IPA) }\end{array}$ & English & French & Turkish & English \\
\hline téléphone & [telefon] & telephone & crayon & kalem & pencil \\
\hline télévision & [televizjon] & television & livre & kitap & book \\
\hline docteur & [doktor] & doctor & chaise & sandalye & chair \\
\hline hélicoptère & [helikopter] & helicopter & ciseaux & makas & scissors \\
\hline biberon & [bibcron] & feeding bottle & table & masa & table \\
\hline collier & [kolje] & necklace & gants & eldiven & gloves \\
\hline fusée & [fyze] & rocket & vélo & bisiklet & bike \\
\hline bicyclette & [bisiklet] & bicycle & nuage & bulut & cloud \\
\hline saucisse & [sosis] & sausage & balai & süpürge & broom \\
\hline canapé & [kanape] & couch & bougie & mum & candle \\
\hline piano & [piano] & piyano & chapeau & şapka & hat \\
\hline robot & [robot] & robot & fourchette & çatal & fork \\
\hline autobus & [otsbys] & bus & parapluie & şemsiye & umbrella \\
\hline bébé & {$[\mathrm{b} \varepsilon b \varepsilon]$} & baby & seau & kova & bucket \\
\hline ananas & [ananas] & pineapple & montre & saat & watch \\
\hline
\end{tabular}




\begin{tabular}{|c|c|c|c|c|c|}
\hline camion & [kamjon] & truck & clé & anahtar & key \\
\hline yaourt & [jourt] & yoghurt & balançoire & salıncak & swing \\
\hline train & [tren] & train & chat & kedi & cat \\
\hline coiffeur & [kwafœr] & hairdresser & raisin & üzüm & grape \\
\hline valise & [valiz] & suitcase & bouteille & şişe & bottle \\
\hline chocolat & [tfikslata] & chocolate & $\begin{array}{l}\text { brosse à } \\
\text { dents }\end{array}$ & diş firçası & toothbrush \\
\hline ballon & [balon] & balloon & & & \\
\hline cheminée & [ œœinin $\varepsilon]$ & fireplace & & & \\
\hline bottes & [bot] & boots & & & \\
\hline zèbre & [zebra] & zebra & & & \\
\hline
\end{tabular}

\subsection{Data Collection and Scoring}

The picture-naming test used for the study was applied to each child individually at school in an office with only the examiner and the child. The visual prompts used for the test were presented in a random order, with the participants in each of the three groups receiving them in the same order. The testing process was videotaped in order to ease transcriptions.

In the bilingual group, all data were first generated in French and, two weeks later, in Turkish. Each child was presented with the images on the computer screen one by one, and was asked each time, "What's the name of this in French/Turkish?". In cases when the child interpreted the image rather than naming it, e.g. saying "you carry patients with this truck" to describe an "ambulance," we noted down this explanation and asked further, e.g. "Yes, but what's the name?" In cases when the child gave a word other than the expected answer, we noted down the answer and recast our question, e.g. "This has another name; do you know it?". If the child's response was negative, we moved on to the next image. If the child gave a wrong answer, we noted this down, and asked "No, that's not the answer. What else can it be?". If the answer was still "I don't know" we moved onto the next image. We noted down all the answers children gave. As our focus in this study is word recognition, we disregarded the pronunciation mistakes in verbal accounts.

In order to analyze the data, we employed the scoring rubric proposed by Pearson et al. (1993):

- Monolingual score is the number of all lexical items in the child's first or second language lexicon,

- Conceptual score: the number of all the concepts in the child's memory. 
In monolingual children, because these two score types overlap, the sum of both scores is equal. As one of our purposes in this study is to compare scores that bilinguals obtain from cognates and non-cognates, we have scored cognates and non-cognates in this group separately.

- The cognate word score: the number of correct naming answers the participant gives for cognates. "Correct answer" means the answer is sufficient for us semantically. This description holds true for "non-cognate scores," as well.

In this study, it is hypothesized that, compared with their monolingual counterparts, French-Turkish speaking bilingual 5-year-olds who are still in the process of learning French and Turkish will

i) show lower performance in word recognition;

ii) acquire equal skills in terms of word recognition at the conceptual level;

iii) show higher performance in word recognition of cognates compare to non-cognate words.

\section{Findings}

Significance of results was checked through a Mann-Whitney statistical test. In order to obtain scores comparing bilinguals' skills in different concepts, scores were expressed as gross scores. Matching our number of test items, the top score is 46 .

\subsection{Results from Bilinguals}

Table 4 shows the distribution of the different scores of the 16 Turkish-French bilingual children in French (BFS) ${ }^{3}$ and Turkish (BTS).

Table 4. Results of Turkish-French speaking bilinguals who use different languages for different concepts.

\begin{tabular}{|l|c|c|c|c|c|c|c|c|c|c|c|c|c|c|c|c|}
\hline & B1 & B2 & B3 & B4 & B5 & B6 & B7 & B8 & B9 & B10 & B11 & B12 & B13 & B14 & B15 & B16 \\
\hline BFS & 24 & 22 & 41 & 35 & 30 & 34 & 34 & 38 & 33 & 39 & 44 & 44 & 39 & 37 & 40 & 37 \\
\hline BTS & 42 & 39 & 42 & 45 & 44 & 40 & 41 & 38 & 31 & 42 & 45 & 42 & 43 & 43 & 42 & 42 \\
\hline CS & 42 & 39 & 44 & 45 & 44 & 42 & 42 & 42 & 39 & 46 & 46 & 46 & 45 & 44 & 44 & 44 \\
\hline
\end{tabular}

Table 4 indicates that except $\mathrm{B} 9$ and $\mathrm{B} 12$, all bilinguals receive better scores in Turkish than French. B8's scores are equal in both languages. Further, the conceptual scores of all participants are higher than their French scores. The

${ }^{3}$ The abbreviations used in Table 4 below are as follows: B1: Bilingual participant number 1; BFS: Bilinguals' score in French; BTS: Bilinguals' score in Turkish; FMS: French Monolinguals' score; TMS: Turkish Monolinguals' score; CS: Conceptual score. 
average point difference between the two scores is 7.68 , with the maximum deviation shown by B1 (18 points), and the minimum deviation shown by B11 and B12 (2 points).

The average standard deviation between total Turkish scores and conceptual scores is relatively low compared with French (ave. 2.06 points). The maximum standard deviation is seen in B9 (8 points) while there is no meaningful difference between scores of monolingual Turkish and conceptual scores, as B1, B2, B4 and B5 indicate.

The lexical items in French that bilinguals fail to recognize seem to be those that are not frequently used at the preschool level, such as household vocabulary. There are cognates among these: "helicopter", "sausage", "yoghurt", "suitcase", "fireplace", "couch."

In line with the findings of previous research (Le Coz \& Lhoste-Lassus 2011), children prefer not to respond to words that they do not know the answer for, and keep silent. We have also detected some mistakes in semantic meanings: e.g. "toothpaste" for "toothbrush"; "radish" for "grapes". Another behavior that we have observed for a couple of words was the participants' choice of indirect explanations, e.g. "birthday cake" for "candle," "milking the cows" instead of "bucket," or "it's plastic" for "bottle". These behaviors have also been observed for Turkish. An unusual behavior was that although the language of picturenaming was Turkish and we asked for Turkish, there were children who gave French responses. Tables 5 and 6 below present the list of words that bilinguals have difficulty naming in French and Turkish. 
Table 5. List of words that bilinguals have difficulty naming in French

\begin{tabular}{llll}
\hline Item & $\begin{array}{l}\text { English } \\
\text { translation }\end{array}$ & $\begin{array}{c}\text { Nb of children } \\
\text { giving wrong answers }\end{array}$ & $\begin{array}{c}\text { \% of children } \\
\text { giving wrong answers }\end{array}$ \\
\hline montre & watch & 12 & 75 \\
canapé & couch & 11 & 69 \\
brosse à dents & toothbrush & 10 & 62 \\
bougie & candle & 9 & 56 \\
balai & broom & 8 & 50 \\
seau & bucket & 7 & 44 \\
raisin & grape & 7 & 44 \\
balançoire & swing & 6 & 37 \\
nuage & cloud & 5 & 31 \\
parapluie & umbrella & 5 & 31 \\
clé & key & 4 & 25 \\
bouteille & bottle & 4 & 25 \\
hélicoptère & helicopter & 4 & 25 \\
saucisse & sausage & 3 & 19 \\
yaourt & yoghurt & 3 & 19 \\
valise & suitcase & 3 & 19 \\
livre & book & 3 & 19 \\
cheminée & fireplace & 3 & \\
\hline & & & 19 \\
\hline
\end{tabular}

Table 6. List of words that bilinguals have difficulty naming in Turkish

\begin{tabular}{|l|l|c|c|}
\hline Item & $\begin{array}{l}\text { English } \\
\text { translation }\end{array}$ & $\begin{array}{c}\text { Nb. of children giving } \\
\text { wrong answers }\end{array}$ & $\begin{array}{c}\text { \% of children giving } \\
\text { wrong answers }\end{array}$ \\
\hline üzüm & grape & 3 & 19 \\
\hline eldiven & glove & 3 & 19 \\
\hline süpürge & broom & 3 & 19 \\
\hline mum & candle & 3 & 19 \\
\hline kova & bucket & 3 & 19 \\
\hline
\end{tabular}

As seen in Table 6, the majority of the items that participants manage to recognize in both languages are cognates, e.g., "piano", "rocket", "hairdresser", "fireplace" and "zebra". These are used by the teachers frequently, as well. For 
these items, the errors were mainly in the absence of answers, with the exception of the item "gloves", which mainly gave rise to visual-semantic errors ("hands").

\subsection{Cross-group Comparisons}

In our first hypothesis in the light of previous research and the experiences of teachers, and speech therapists, we have advanced that compared with their monolingual peers, bilingual 5-year-olds who are still learning French would prove weaker in picture-naming tests.

In these tests, bilinguals scored an average of 35.68 points in French (Standard Deviation: 6.24), while the average score of their monolingual French peers is 45.81 (SD: 0.544). Statistical tests show a meaningful difference between the two groups $(p .<0.0001)$. Therefore, our hypothesis has been confirmed.

Figure 2. Comparison of conceptual score average performance between bilinguals and their French peers

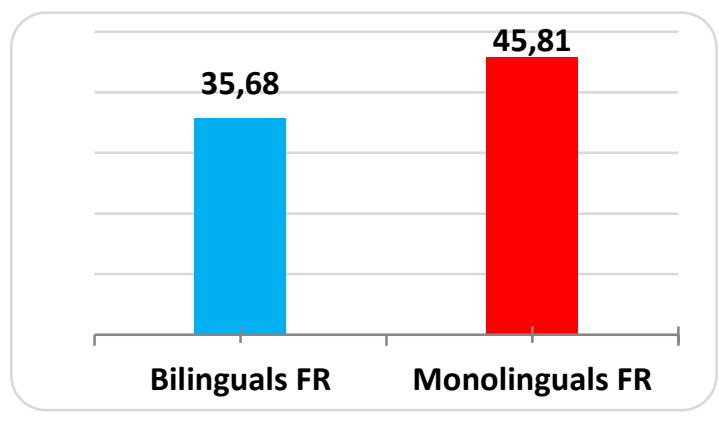

The results comparing the bilinguals' average scores in Turkish with the monolinguals' are significantly different from those in French. Bilinguals obtained an average score of 21.25 in picture-naming task in Turkish (SD: 1.98), while monolinguals scored 22.25 (SD: 0.85). In Turkish, there is no statistically significant difference between the two groups $(p=0.140)$. The bilinguals born and raised in France show similar performances with their peers in their first language. 
Figure 3. Comparison of conceptual scores in Turkish between bilinguals and their Turkish peers

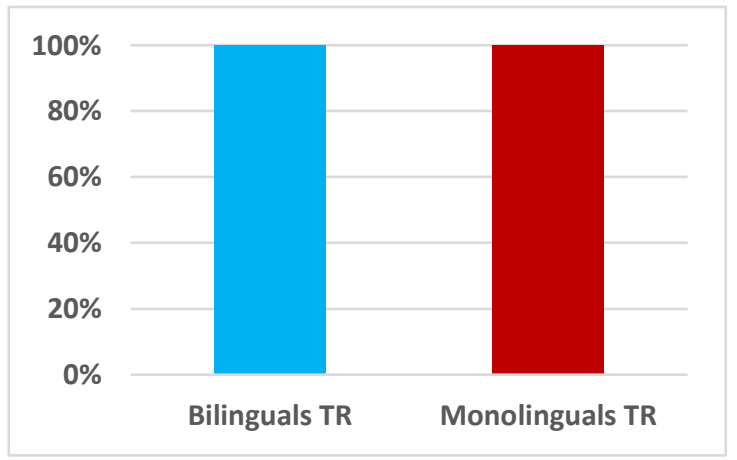

4.3 Comparison of Word Production in Cognate and Non-cognate Words

In our third hypothesis, we predicted that bilingual children would score higher in cognate production compared to non-cognate production.

Figure 4. Comparison of cognate and non-cognate production in bilingual Turkish-French speaking children and monolingual French-speaking

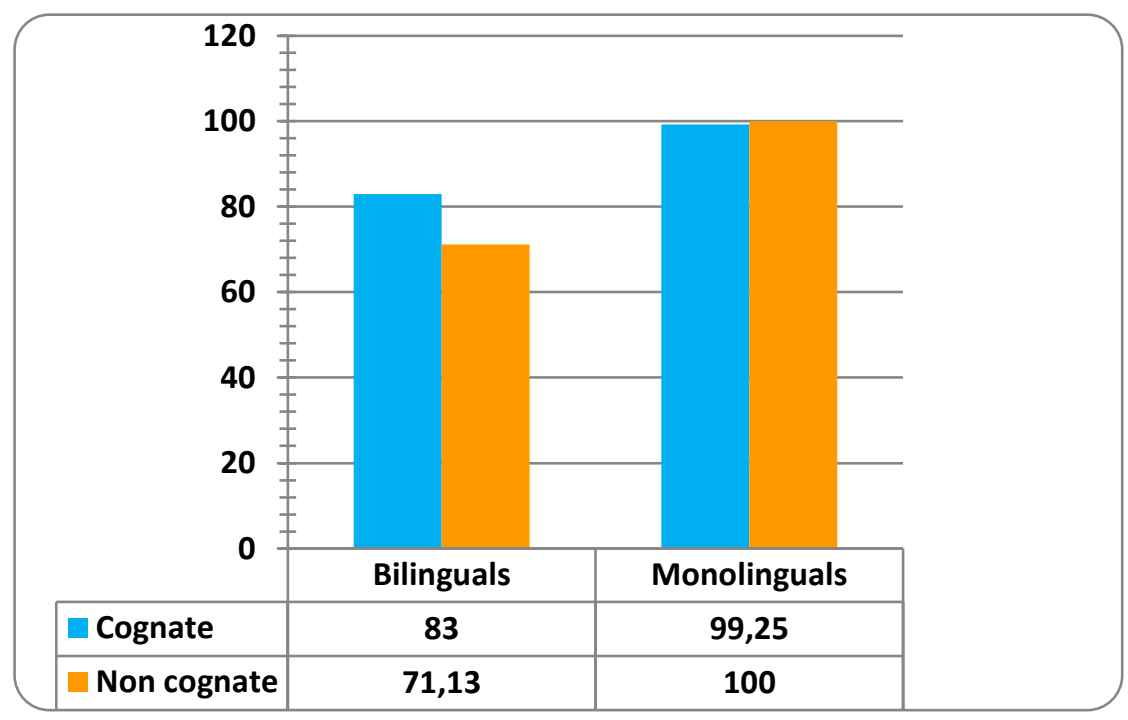


When we compare the success rate in cognate and non-cognate production of monolingual French children, we have the following results: the success rate in cognate words is $99.25 \%$, while this percentage is $100 \%$ in non-cognates. When these percentages are analyzed statistically, there is no significant difference $(p=0.164)$.

In the case of bilinguals, the success rate of these children in cognate production is $83 \%$, while it is $71.13 \%$ in non-cognates. When this result is compared statistically, the difference is found to be meaningful $(p=0.022)$. Confirming our third hypothesis; this result indicates that bilingual children are more successful in producing cognates.

\subsection{The Relationship between Word Production Performance and Word Use Frequency in Bilinguals' French}

Our statistical analyses have revealed a meaningful relationship $(p=0.002)$ between non-cognate production performance and word use frequency in bilingual French speaking children. Similarly, it is revealed that cognate production performance and word use frequency are in a meaningful relationship, as well $(p<0.0001)$. In other words, more frequently encountered words are produced more accurately by these children.

\subsection{Monolingual Turkish Children's Use of Other Words in Place of Cognates}

As we have shown above, and confirmed by research, there is a Turkish equivalent for every word that was borrowed from French. Table 7 below shows the list of answers provided frequently by monolingual Turkish participants in place of cognates. Although participants have proven upon second inquiry that they knew the expected cognate, it is seen that they have other preferences.

Table 7. Monolingual Turkish children's use of other words in place of cognates

\begin{tabular}{llccc}
\hline \multirow{2}{*}{ item } & \multicolumn{2}{c}{ Synonyms } & \multicolumn{2}{c}{ Other } \\
\cline { 2 - 5 } & answer & $\begin{array}{c}\% \text { of this } \\
\text { answer }\end{array}$ & answer & $\begin{array}{c}\% \text { of this } \\
\text { answer }\end{array}$ \\
\hline füze (fusée) & roket & 85 & & \\
valiz (valise) & bavul & 35 & çanta (sac) & 25 \\
şömine (cheminée) & & & soba (poële) & 45 \\
bot(botte) & çizme & 30 & & 20 \\
sosis (saucisse) & sucuk & 25 & & \\
\hline
\end{tabular}




\section{Discussion and Conclusion}

Based on studies conducted in this topic so far, we have focused on vocabulary production among French-Turkish speaking, French and Turkish-born children of 5 years of age. It is often assumed in researches that young bilinguals are lexically delayed in comparison to monolinguals (de Houwer et al. 2013) and that bilingual children are not able to activate both languages in their brain when speaking. In order to check these questions, we compared cognate and noncognate production in their French and Turkish.

Concerning the failed items in French by bilingual children, we observed that they were mainly items relating to domestic life ("toothbrush", "watch", "couch", "broom", "swing"). This seems comprehensible if we admit that the child acquires and uses their languages in different fields (Grosjean, 2010). If bilingual children do not know the French word, it is certainly because, until then, they have been little exposed to these words and, because they have not been exposed to them, or they may not have really needed to use them in this language yet.

If the slightest experience of bilingual subjects with French constitutes a fairly probable explanation for the fact that at the age of 5, they still have not caught up with the monolingual standard, another factor allows us to think that this undertaking will be particularly difficult for French-Turkish bilinguals. Indeed, Laufer (1994: 3) states that "Words which contain phonemes or combinations of phonemes which do not exist in L1 may be difficult to perceive correctly; in production, they are often mispronounced, while learners, who are particularly aware of their pronunciation errors, do not completely avoid using them". Typological distance between French and Turkish languages in terms of phonology could constitute an additional source of difficulty for them. Difficulties in the appropriation of the French phonological system could cause a less efficient encoding of the form of words in French and thereby limit the increase in the lexical stock in this language. This explanation was also advanced by Chalumeau \& Efthymiou (2010) in response to the observation that early sequential Portuguese-speaking bilingual children had a greater active lexical stock than their Turkish-speaking bilingual peers in France. It would then be interesting to test our Turkish background bilinguals with a repetition test in addition to our picture-naming test in order to observe the possible relation between a phonological insufficiency and the lack of response to certain items. For instance, we also found the item "table" causing a problem for two children who first used the term "tableau" (board) before self-repairing. This error is probably due to the formal proximity between these words.

Mainly French-Turkish bilingual children when faced with an item that they cannot name in French failed to offer a response. That is why it is difficult for us to identify a typology of errors. We should emphasize that during both tests, in French and in Turkish, bilingual children seemed overall less confident and more 
reserved than their monolingual French-speaking peers. This can be explained by having difficulty answering in a language that is not yet very well mastered, the same attitude during tests in Turkish can be explained by the unprecedented nature of the situation for these children.

We observed also great heterogeneity in French of bilingual children, which leads us to mention some factors that may have an influence on language learning.

The quantity and quality of the input are said to be determining factors in the acquisition of a language (Comblain \& Rondal, 2001; Granfeldt, 2016). None of the French-Turkish bilinguals really began their French language acquisition until they entered preschool. So, they were all able to benefit from the same length of exposure to French and it is legitimate to think that school provided them all with the same quantity and quality of input. Nonetheless, we have seen from responses to a questionnaire filled out by families that while Turkish is predominantly the language spoken at home, French is not completely absent. Some children benefit from additional experience of French through one of their parents (born in France) or their elders. This may have helped to increase their French vocabulary. Comparing data concerning language practices within families with results of children, we have not identified any typical situation allowing us to explain better performance of some children compared to others. It is really difficult to measure the benefit for a child of an additional contact with French through relatives (parents, elders) as this benefit depends on these persons' mastery of French. The child's motivation and interest in learning French can also be a major source of variation in the level of mastery of this language.

All bilingual children obtain a conceptual score higher than their Frenchspeaking monolingual score. This attests to the fact that their knowledge is distributed among their two languages. Also, this finding supports the idea according to which the evaluation of the vocabulary of a bilingual child as part of a more global evaluation of his language competence can only be understood from the Complementarity Principle (Grosjean, 2010). To consider only the monolingual score of the child would be to obscure part of his competence.

We hypothesized that bilingual children would obtain a conceptual score equivalent to that of their French-speaking monolingual peers. We have seen that our results do not allow us to validate this hypothesis. If this hypothesis had turned out to be valid, it would have enabled us to rule out difficulties located at the signified level, within the limit of items proposed in our test of course. However, the converse is not true. The conceptual score refers here to the number of concepts that a child is able to evoke through a signifier. It is therefore possible that for items causing the conceptual score to drop, the concept is known to the child but they are not yet able to evoke it through a signifier. The fact that bilinguals obtain a conceptual score significantly lower than that of their French- 
speaking monolingual peers does not therefore allow us to assert that their difficulties lie at the level of the signified. A designation test covering the same items as those in our test would have allowed us to know more about this.

However, the fact that 5-year-old bilingual children obtain a lower conceptual score than that of French-speaking monolinguals allows us to affirm that they have a more limited production lexicon than their French-speaking peers, even though the latter is considered to be more limited through their two languages. This can be explained by the "late" introduction of French for these children, that is to say when they enter preschool. Indeed, as Akinci (2008: 66) states, "In an ordinary monolingual situation, school is a place where the child deepens his knowledge of his mother tongue. While for children from migrant families, this linguistic continuity is not ensured by school". For early sequential bilingual children, entering school therefore represents "a break in the process of language knowledge". Indeed, if monolingual children, already having a usual vocabulary in French, will be able, when they enter school, to devote themselves to enriching their lexicon, the task that bilingual children will have to accomplish will be different. They will have to acquire French signifiers of concepts already lexicalized in Turkish, in other words to learn the translation equivalents of words already known in Turkish, and to lexicalize new concepts in each of their languages, i.e., to pursue to enrich their vocabulary in their two languages.

Our results differ from those obtained in previous studies (Pearson et al., 1993; Junker \& Stockman, 2002; Zablit \& Trudeau, 2008) carried out with early simultaneous bilinguals which highlighted the fact that they obtained equivalent scores to those of their monolingual peers when one relied on their conceptual score for comparison with their monolingual peers. This can be explained by the fact that early simultaneous bilinguals being confronted with both languages from birth, they did not face with a break in the acquisition of their languages.

Our results therefore underscore the specificity of the early sequential bilingualism in relation to that of monolingualism but also in relation to that of early simultaneous bilingualism. Based on this, it seems that when testing vocabulary of a bilingual child, in the broader context of a language competencies, if it seems adequate for early simultaneous bilingualism, use of the conceptual score for a strict comparison to a monolingual norm is not very relevant for early sequential bilingualism. Indeed, this comparison could lead us to the conclusion that these children have a lexical deficit while their lexical development is normal for them.

The fact that bilingual children obtain a conceptual score equivalent to that of their Turkish-speaking monolingual peers caught our attention. One of the probable explanations lies in the degree of difficulty presented by our test depending on the culture considered. Thus, our test turned out to be more difficult for Turkish-speaking monolinguals than for French-speaking monolinguals. Two of our items have for instance contributed to lowering the average of Turkish- 
speaking monolinguals" performance. These are "pineapple" and "zebra" items. It is possible that these words are less significant in Turkish culture than they are in French culture, which could be at the origin of a later acquisition of these words by Turkish-speaking children than by French-speaking children. However, we can therefore consider that it was easier for bilinguals to join the Turkish monolingual standard than the French monolingual standard. One might then think that bilinguals ultimately behave like Turkish monolinguals. If quantitatively, this seems true for our test, it is not qualitatively so since the items mostly failed by bilinguals are not the same as those mostly failed by Turkish monolinguals. Items such as "zebra" and "pineapple" led to few errors for bilinguals. Therefore, it is necessary to consider bilinguals following a different learning strategy in terms of lexicon from that of their monolingual peers, a strategy marked by their two cultures.

As another result, French-born 5-year-old bilinguals performed higher in cognate words compared with non-cognate words. This finding proves that bilingual children know more cognates. This result questions, on the one hand, the view that a bilingual person using a second language would not refer to their first language repertoire; while, on the other hand, supports the extent of bilinguals' parallel language activation.

This result also suggests that bilinguals do not learn these words twice but transfer their knowledge from one language to another. Nevertheless, we should be cautious because, as we mentioned, results in French of the bilingual children appears to be linked to the frequency of the subjects' encounter (estimated by their teachers) with the target words. This correlation appears for both cognate and non-cognate items. Therefore, we cannot rule out the idea that the observed cognate effect is actually a frequency effect. In addition, it is possible that other variables linked to the images offered and their labels, and not studied here, such as the degree of concreteness, conceptual familiarity or even the emotional valence of the target words, among others, have contributed to the differences between these two groups of items (cognates $v s$ non-cognates). We were nevertheless able to observe another phenomenon which allows us to think that bilinguals use knowledge of their L1 to increase their lexicon in L2. If we have not found the same result observed by Le Coz and Lhoste-Lassus (2011) with the item "vélo" (bicycle), bilinguals" preferential was "bicyclette" compared to all French monolinguals who preferred "vélo", we observed a similar phenomenon with the item "bus". Half of the bilinguals used the word "bus", while all Frenchspeaking monolinguals used either the word "car" or the word "bus". Knowing that "autobus/otobüs" is the word used in Turkish for this item and that in French this word is used very few by children of this age, we can deduce that bilingual children transferred this word from Turkish to French. However, if in order to learn these particular translation equivalents that are cognates, bilingual children transfer their knowledge from one language to another, how can we explain the 
fact that among items passed in Turkish but failed in French we find cognate items? In other words, why is it that for certain items, the formal proximity between the translation equivalents does not seem to have played a facilitating role? This scenario is notably represented by the item "couch" which was passed by all bilinguals in Turkish but failed by 11 of them in French. It is possible that they were not sufficiently in contact with this word in French to be able to identify the formal similarity between the translation equivalents and to effect a transfer from one language to another. Another explanation that we could provide comes from the analysis of the bilinguals' answers in Turkish. We observed that of the 11 bilingual children who passed this item in Turkish but failed it in French, 8 of them had not produced the cognate word "kanepe" in Turkish but the word "koltuk", a synonym. We can therefore assume that it is necessary for the cognate word to be familiar enough to the child in their L1 for the latter to be able to identify the formal proximity between the translation equivalents. During the construction of our test, we were aware of the possibility of observing this phenomenon, namely the production of a correct answer in Turkish but other than the expected cognate term, since we knew that most of the terms borrowed from French into Turkish had a synonym (i.e., problem / sorun). In future studies, it would be interesting to control this parameter in order to be able to better identify transfers between languages.

Cognate words are the center of multiple proximities (orthographic, phonological, morphological or semantic), and it remains difficult to understand precisely the treatment of words which maintain so many similarities. Systematic research on the role of the various codes concerned (spelling, phonological and semantic codes) during language processing in bilinguals seems necessary to understand the processes of access to the organization of the bilingual mental lexicon as a whole.

\section{References}

Akinci, M.A. (2001). Développement des compétences narratives des enfants bilingues turc-français en France âgés de 5 à 10 ans, München: LINCOM.

Akinci, M.A. (2006). Du bilinguisme à la bilittéracie. Comparaison entre élèves bilingues turc-français et élèves monolingues Français. Langage et Société, 116(2), 93-110.

Akinci, M.A. (2008). Language use and biliteracy practices of Turkish-speaking children and adolescents in France. In V. Lytra \& J.N. Jorgensen (Eds.), Multilingualism and Identities across Contexts: Cross-disciplinary perspectives on Turkish-speaking youth in Europe, (pp. 85-108). Copenhagen: University of Copenhagen Press.

Akinci, M.A. \& Decool-Mercier, N. (2010). Aspects of language acquisition and disorders in Turkish-French bilingual children. In S. Tobbaş \& M. Yavaş (Eds.), Communication Disorders in Turkish in monolingual and multilingual settings, (pp. 312-351). Clevedon: Multilingual Matters.

Bogaards, P. (1994). Le vocabulaire dans l'apprentissage des langues. Paris: Didier. 
Bornstein, M. H., Cote, L. R., Maital S., Painter K., Park, S.Y., Pascual, L., Pêcheux M.G., Ruel J., Venuti, P. \& Vyt, A. (2004). Cross Linguistic Analysis of Vocabulary in Young Children: Spanish, Dutch, French, Hebrew, Italian, Korean, and American English. Child Development, 75(4), 1115-1139.

Brenders, P., Van Hell, J. G., \& Dijkstra, A. (2011). Word recognition in child second language learners: Evidence from cognates and false friends, Journal of Experimental Child Psychology, 109(4), 383-396.

Broersma, M., Carter, D. \& Acheson, D.J. (2016). Cognate costs in bilingual speech production: Evidence from language switching. Frontiers in Psychology, 7/1461, 116.

Chalumeau, S. \& Efthymiou, H. (2010). Le bilinguisme précoce consécutif chez les enfants lusophones et turcophones: influence de la langue maternelle sur l'acquisition $d u$ français langue seconde. Unpublished MA thesis, Lyon: Université Claude Bernard Lyon 1, ISTR, Ecole d'Orthophonie.

Comblain, A. \& Rondal, J.A. (2001). Apprendre les langues : Où ? Quand? Comment?. Liège: Mardaga.

Comesaña, M., Soares, A.P. \& Lima. C. (2010). Semantic representations of new cognate vs. non cognates words: Evidence from two second language learning methods. Procedia Social and Behavioral Sciences, 5, 199-203.

Costa, A. \& Caramazza, A. (1999). Is lexical selection in bilingual speech production language- specific?. Further evidence from Spanish-English and English-Spanish bilinguals. Bilingualism: Language and Cognition, 2/3, 231-244.

Costa, A., Caramazza, A. \& Sebastian-Galles, N. (2000). The cognate facilitation effect: Implications for models of lexical access. Journal of Experimental Psychology: Learning, Memory, \& Cognition, 26, 1283-1296.

Costa, A., Miozzo, M. \& Caramazza, A. (1999). Lexical selection in bilinguals: Do words in the bilingual's two lexicons. compete for selection? Journal of Memory and Language, 41, 365-397.

Costa, A., Santesteban, M. (2004). Lexical access in bilingual speech production: Evidence from language switching in highly proficient bilinguals and L2 learners. Journal of Memory and Language, 50, 491-511.

Costa, A., Santesteban, M. \& Cano, A. (2005). On the facilitatory effects of cognate words in bilingual speech production, Brain and Language, 94/1, 94-103.

Costa, A., Santesteban, M. \& Ivanova, I. (2006). How do highly proficient bilinguals control their lexicalization process?. Inhibitory and language-specific selection mechanisms are both functional. Journal of Experimental Psychology: Learning, Memory, and Cognition, 32 (5), 1057-1074.

de Groot, A.M.B. (1993). Word-type effects in bilingual processing tasks: support for a mixed representational system, R. Schreuder \& B. Weltens (Eds.), The bilingual lexicon. Amsterdam: John Benjamins, 27-51.

de Houwer, A. (2010). Assessing lexical development in bilingual first language acquisition: What can we learn from monolingual norms? In M. Cruz-Ferreira (Ed.), Multilingual norms, Frankfurt: Peter Lang.

de Houwer A., Bornstein M.H. \& Putnick D.L. (2013). A bilingual-monolingual comparison of young children's vocabulary size: Evidence from comprehension and production. Applied Psycholinguistics, 35(6), 1189-1211. 
Dijkstra, T., Grainger, J., \& Van Heuven, W. J. B. (1999). Recognition of cognates and interlingual homographs: The neglected role of phonology. Journal of Memory and Language, 41, 496-518.

Dijkstra, T., Miwa, K., Brummelhuis, B., Sappelli M. \& Baayen, H. (2010). How cross language similarity and task demands affect cognate recognition. Journal of Memory and Language, 62, 284-301.

Ertek, B. (2017). Développement du vocabulaire en turc et en français d'élèves bilingues franco-turcs et monolingues turcs et français âgés de 6 ans à 10 ans. Unpublished $\mathrm{PhD}$ dissertation, Rouen: Université de Rouen Normandie.

Font, N. \& Lavaur, J.M. (1998). Représentation des mots cognats et non cognats en mémoire chez les bilingues français-espagnol. Psychologie Française, 43/4. 329-338.

Genesee, F., Paradis, J. \& Crago, M.B. (2011). Dual language development and disorders. A handbook on bilingualism and second language learning, Baltimore MD: Brookes.

Gollan, T.H. \& Acenas, L.A.R. (2004). What Is a TOT?. Cognate and Translation Effects on Tip-of-the-Tongue States in Spanish-English and Tagalog-English Bilinguals, Journal of Experimental Psychology: Learning, Memory, and Cognition, 30/1, 246269.

Granfeldt J. (2016). Rôles de l'âge, de l'input et de la L1 dans le développement du français par des enfants L2. Revue Française de Linguistique Appliquée, 21/2, 33-48.

Green, D. W. (1998). Mental control of the bilingual lexico-semantic system, Bilingualism: Language and Cognition. 1, 67-81.

Grosjean, F. (2010). Bilingual: Life and reality, Cambridge, Harvard University Press.

Hamurcu-Süverdem, B. (2015), Développement du turc et du français en situation de bilinguisme précoce. Le cas d'enfants d'origine turque scolarisés en maternelle. Unpublished $\mathrm{PhD}$, Rouen: Université de Rouen.

Ivanova, I. \& Costa, A. (2008). Does bilingualism hamper lexical access in speech production?. Acta Psychologica, 127/2, 277-288.

Junker, D.A. \& Stockman, I.J. (2002). Expressive vocabulary of German-English bilingual toddlers. American Journal of speech-Language Pathology, 11, 381-394.

Kara, N. (2011). Contribution à l'intercompréhension entre le turc et le français: les transparences lexicales. Unpublished MA thesis, Reims: Université de Reims Champagne-Ardenne.

Kohnert, K. (2004). Cognitive and cognate-based treatments for bilingual aphasia: A case study. Brain and Language, 91/3, 294-302.

Kroll, J.F. \& de Groot, A.M.B. (1997). Lexical and conceptual memory in the bilingual: Mapping form to meaning in two languages. In A.M.B. de Groot \& J.F. Kroll (Eds.), Tutorials in bilingualism: Psycholinguistic perspectives, (pp. 169-199), Mahwah, NJ: Lawrence Erlbaum Associates Publishers.

Kroll, J.F. \& Stewart, E. (1994). Category interference in translation and picture naming: evidence for asymmetric connections between bilingual memory representations. Journal of Memory and Language, 33/2, 149-174.

Kroll, J.F., Bobb, S.C., Misra, M. \& Guo T. (2008). Language selection in bilingual speech: Evidence for inhibitory processes. Acta Psychologica, 128, 416-430.

Laufer, B. (1994). Appropriation du vocabulaire : mots faciles, mots difficiles, mots impossibles. AILE Acquisition et Interaction en Langue Etrangère, 3, 97-113. 
Le Coz, A. \& Lhoste-Lassus, A. (2011). Compétences lexicales et morphosyntatiques des enfants bilingues franco-turcs de grande section de maternelle: comparaison avec leurs pairs monolingues français. Unpublished MA thesis, Lyon, Université Claude Bernard Lyon 1, ISTR, Ecole d'orthophonie.

Manigand, A. (1999). Le silence des enfants turcs à l'école. Psychologie \& Éducation, 37, 57-73.

Morrison, C. M., Chappell, T. D. \& Ellis, A. W. (1997). Age of acquisition norms for a large set of object names and their relation to adult estimates and other variables. Quarterly Journal of Experimental Psychology: Human Experimental Psychology, $50 \mathrm{~A} / 3,528-559$.

Oker, A. \& Akinci, M. A. (2012). Processus implicite de dénomination de mots chez des enfants bilingues franco-turcs de 5 ans. CogniTextes, 8. http://cognitextes.revues.org/626.

Pearson, B.Z., Fernandez, S.C. \& Oller, D.K. (1993). Lexical Development in Bilingual Infants and Toddlers: Comparison to Monolingual Norms. Language Learning, 43/1, 93-120.

Poarch, G.J. \& Van Hell, J.G. (2012). Cross-language activation in children's speech production: Evidence from second language learners, bilinguals, and trilinguals. Journal of Experimental Child Psychology, 111/3, 419-438.

Sağlam, M.Y. (2007). Türkçe'deki Terim Sorunsal1. Türkbilig, 14, 168-176.

Woutersen, M., de Bot, K. \& Weltens, B. (1995). The bilingual lexicon: Modality effects in processing. Journal of psycholinguistic research, 24, 289-298.

Yan, X. (2014). Cognate words picture naming in non-alphabetic languages: evidence from Cantonese-Mandarin bilinguals. Unpublished MA thesis, Hong Kong: The University of Hong Kong, Faculty of Education.

Zablit, C. \& Trudeau, N. (2008). Le vocabulaire chez les jeunes enfants libanais arabophones, francophones et bilingues. Glossa, 10, 36-52. 